\title{
13. COMPARISON OF THE MAGNETIC AND BIOSTRATIGRAPHIC TIME SCALES SINCE THE LATE CRETACEOUS
}

\author{
John G. Sclater, Department of Earth and Planetary Sciences, Massachusetts Institute of Technology, Cambridge, \\ Massachusetts \\ Richard D. Jarrard, Scripps Institution of Oceanography, University of California at San Diego, La Jolla, California \\ Brian McGowran, School of Geology, University of Adelaide, Adelaide, South Australia \\ and \\ Stefan Gartner, Jr., Rosenstiel School of Marine and Atmospheric Sciences, University of Miami, Miami, Florida
}

\section{INTRODUCTION}

One of the major achievements of the Deep Sea Drilling Project has been the discovery of evidence which presents strong support for the theory of sea-floor spreading. The age of the oldest sediment overlying basement determined from the biostratigraphic time scale of Berggren (1972) has been close to that predicted by the magnetic anomaly time scale of Heirtzler et al. (1968). This agreement is surprisingly good considering the problems that erosion, nondeposition of sediment, renewed vulcanism, and uncertainties in absolute dating of geologic epochs give to the biostratigraphic dating of the underlying basaltic rock. However, at sites with good basal sediment-basement contacts drilled on identifiable magnetic anomalies older than anomaly 13 (Sites 19, 20, 39), the magnetic anomaly age is consistently 5 to $8 \mathrm{~m} . \mathrm{y}$. older than the biostratigraphic age of the oldest sediments (Table 1). This difference has not received much attention prior to Leg 22.

Site 213 was drilled on the younger side (north) of anomaly 26 which has been clearly identified in this region by Sclater and Fisher (in preparation). This anomaly has an age of 64 m.y. B.P. according to the time scale of Heirtzler et al. (1968). At Site 213 an excellent sediment basement contact was recovered, and the foraminifera and nannofossils were observed in entrapped sediment between the weathered basaltic pillows. Both groups of microfossils gave an age of 56 to 58 m.y. B.P., which is significantly less than that given by the identification of the magnetic anomalies (Table 1).

At Site 216 on the Ninetyeast Ridge Latest Cretaceous sediments overlay an extrusive basalt which was radiometrically dated at $64 \pm 1$ m.y. B.P. McDougall (Chapter 12). The sediments immediately above straddle the Cretaceous/Tertiary boundary. Thus, the radiometric age of the basalt gives a maximum possible age of $64 \pm 1$ m.y. B.P. for this boundary. Berggren's (1972) marine extension of the land based biostratigraphic time scale assumes an absolute age of 65 m.y. B.P. for the Cretaceous/Tertiary boundary. A recent unpublished compilation of radiometric ages by the late Edwin Allison (San Diego) gave a mid-continent North America date for this boundary of $63 \pm 2$ m.y. B.P. The radiometric age at Site 216 and the compilation of Allison are considered positive evidence that his assumption is in error by less than 2 m.y. for the Late Cretaceous/early Tertiary boundary. Thus, the differences between the magnetic and biostratigraphic ages at Site 213 and the other sites mentioned above cannot be attributed to uncertainties in the absolute dating of the geologic epochs. There is a widespread hiatus in the Pacific and Atlantic between the mid-Eocene and late Maastrichtian. It was originally thought that this hiatus, coupled with unusually low sedimentation, could account for the younger biostratigraphic ages at Sites 19, 20, and 39 . However, these factors cannot explain the younger biostratigraphic age at Site 213 in the Indian Ocean where there is no evidence for a mid-Eocene to late Maastrichtian hiatus. The most plausible explanation of the age difference at the four sites is a 5 to $8 \mathrm{~m} . \mathrm{y}$. error in the early Tertiary portion of the magnetic time scale.

Such an error in the early Tertiary is of major significance for sites drilled on Leg 22. Sclater and Fisher (in preparation) have shown that between anomalies 23 and 32 the average half-spreading rate on either side of the Ninetyeast Ridge is close to $10 \mathrm{~cm} / \mathrm{yr}$. Since the oceanic crust on the two sides of the ridge has been formed by spreading in opposite directions, a 7-m.y. discrepancy between the magnetic and biostratigraphic age could yield a $700-\mathrm{km}$ uncertainty in position when compared with magnetic anomalies on the same side of the Ninetyeast Ridge. If the biostratigraphic age were compared with anomalies on the other side of the ridge, the relative uncertainty could be as much as $1400 \mathrm{~km}$. This potential discrepancy is so serious that in this paper we developed our own relationship between the distinctive numbered magnetic anomalies of Pitman and Heirtzler (1966) and Heirtzler et al. (1968) and the absolute ages assigned to the geological epochs by Berggren (1972). We have deliberately not attempted an update of the magnetic time scale of Heirtzler et al. (1968). Such an update must await the results from later Deep Sea Drilling legs, especially 24, 25 , 28 , and 32 , further detailed analysis of the older anomalies to investigate the possibility of hidden short events, and a careful consideration of the ages given by Tertiary and later reversals dated on land and in the JOIDES Deep Sea Drilling Project cores.

\section{CRITERIA FOR SELECTING RELIABLY DATED ANOMALIES}

All the published Initial Reports and Geotimes articles up to and including Leg 22 were examined for sites on or close to identifiable magnetic anomalies with a good sediment basement contact. There are 13 such sites $(10,14$, $15,16,17,19,20,32,34,36,39,75$, and 213 , Peterson et al., 1970; Maxwell et al., 1970; McManus et al., 1971; Tracey et al., 1971; von der Borch et al., Chapter 24, this 
TABLE 1

Age Data for Sites with Good Basal Sediment-Basement Contacts

\begin{tabular}{|c|c|c|c|c|}
\hline & \multicolumn{4}{|c|}{ JOIDES Deep Sea Drilling Site } \\
\hline & $19^{\mathrm{a}}$ & $39^{b}$ & $213^{\mathrm{c}}$ & $20^{\mathrm{a}}$ \\
\hline Magnetic anomaly & $\begin{array}{l}\text { Just before } \\
\text { younger side } \\
\text { of } 21\end{array}$ & $\begin{array}{l}\text { Extrapolated } \\
\text { older side } \\
\text { of } 24\end{array}$ & $\begin{array}{l}\text { Younger side } \\
\text { of } 26\end{array}$ & $\begin{array}{l}\text { Older side } \\
\text { of } 30\end{array}$ \\
\hline $\begin{array}{l}\text { Estimated age from } \\
\text { the Heirtzler et al. } \\
\text { time scale }\end{array}$ & $53-55$ & $60-62$ & $63-65$ & $70-72$ \\
\hline \multicolumn{5}{|l|}{ Biostratigraphic zones: } \\
\hline Foraminifera & $\begin{array}{l}\text { Hantkenina } \\
\text { aragonensis }\end{array}$ & P-6 & $\mathrm{P}-4$ & - \\
\hline Nannofossils & $\begin{array}{l}\text { Chiphragmalithus } \\
\text { quadratus }\end{array}$ & $\begin{array}{l}\text { Marthasterites } \\
\text { tribrachiatus }\end{array}$ & $\begin{array}{l}\text { Discoaster } \\
\text { mohleri }\end{array}$ & $\begin{array}{l}\text { Tetralithus } \\
\text { murus }\end{array}$ \\
\hline \multicolumn{5}{|l|}{$\begin{array}{l}\text { Estimated age based } \\
\text { on biostratigraphic } \\
\text { data: }\end{array}$} \\
\hline Foraminifera & $\begin{array}{l}\sim 47 \\
\sim 48\end{array}$ & $52-54$ & $56-58$ & - \\
\hline Nannofossils & $46-48$ & $51-52$ & $57-58$ & $65-67$ \\
\hline \multicolumn{5}{|c|}{ References: } \\
\hline $\begin{array}{l}\text { a Sites } 19 \text { and } 20 \text { fro } \\
\text { b Site } 39 \text { from McM } \\
{ }^{c} \text { Site } 213 \text { from this }\end{array}$ & $\begin{array}{l}\text { rom Maxwell et al. } \\
\text { Ianus et al. (1970). } \\
\text { s volume (Chapter } 2\end{array}$ & $\begin{array}{l}\text { 1970). } \\
\text { 4). }\end{array}$ & & \\
\hline
\end{tabular}

volume, which were then scrutinized carefully. Site 10 from Leg 2 was rejected because the identification of anomaly 31 by Pitman and Talwani (1972) is tentative. These authors recognized anomaly 33 to the east of the mid-Atlantic Ridge and based their identification of anomaly 31 to the west of the ridge on the assumption of symmetrical spreading (Pitman, personal communication). The Atlantic sites from Leg 3 were replotted onto the V-20 profiles of Dixon et al. (1968) and the magnetic identification double-checked. Site 17 was rejected as the identification, though close to anomaly 13 , is unclear. The Pacific sites from Leg 5 were superimposed on the bathymetric charts of Chase et al. (1970) and also on the original magnetic profiles used by Atwater and Menard (1970) in their identification of the anomalies in the northwestern Pacific. Site 34 was rejected because there are 28 meters between the lowermost dated sediments and basement. Site 36 is very complex. The site is close to two prominent seamounts and is in a region of unclear magnetic lineations between anomalies 4 and the end of 5 . It is also within $50 \mathrm{~km}$ of the Mendocino Fracture Zone. However, there is a clear anomaly profile south of the site indicating that the fracture zone influence is negligible. The discrepancy between the biostratigraphic ages and the magnetic age is disturbing. This site has been plotted on Figure 1 but was rejected in computing a time scale because the nannofossil and foraminifera ages disagree by almost 3 m.y. B.P., and there is some evidence of reworking in the lowermost cores (McManus et al., 1970, p. 207). Site 39 does not lie on a magnetic anomaly profile. However, it is located in undisturbed topography some $40 \mathrm{~km}$ south of a profile showing a clear anomaly 24 . For this reason it has been included in the compilation. Site 75 in the Pacific was rejected as the basement sediment contact is not good, and the identification of anomaly 13 is not convincing on either the profiles shown by Herron (1972) or Mammerickx et al. (unpublished manuscript). After examining the sites carefully only eight remain-14,15,16, 19, and 20 from Leg 3 ; 32 and 39 from Leg 5; and 213 from Leg 22 (Table 2). Of these only 213,20 , and 19 have fossils intercalated with the basaltic flows.

\section{COMPARISON OF TIME SCALES}

The Heirtzler et al. (1968) time scale is based on the identification and matching of anomalies from profile V-20 in the south Atlantic with a time scale based on a date of 3.36 m.y. B.P. for the beginning of the Gauss normal polarity epoch (Dalrymple, 1972). The matching gave a spreading rate of $1.9 \mathrm{~cm} / \mathrm{yr}$. This rate was then assumed to be constant for the whole length of the profile and the ages of the older anomalies were determined; under these assumptions the age of anomaly 31 is 71.5 m.y. B.P. The major justification for this extrapolated time scale is that anomaly 31 lies at the foot of the Rio Grande Rise and close to a core where a Late Cretaceous fossil was recovered (Saito et al., 1966).

There is considerable evidence from magnetic anomaly profiles in the Indian Ocean and the north Pacific for a short positive period in the negative between anomalies 32 and 33. Thus for the Late Cretaceous portion of the time scale, anomalies 31 and 32, the McKenzie and Sclater (1971) modification of the Heirtzler time scale between 70 and 77 m.y. BP (Figure 1) has been used. In this paper all anomalies are numbered at the end of their respective period of normal polarity. 
TIME, MYBP
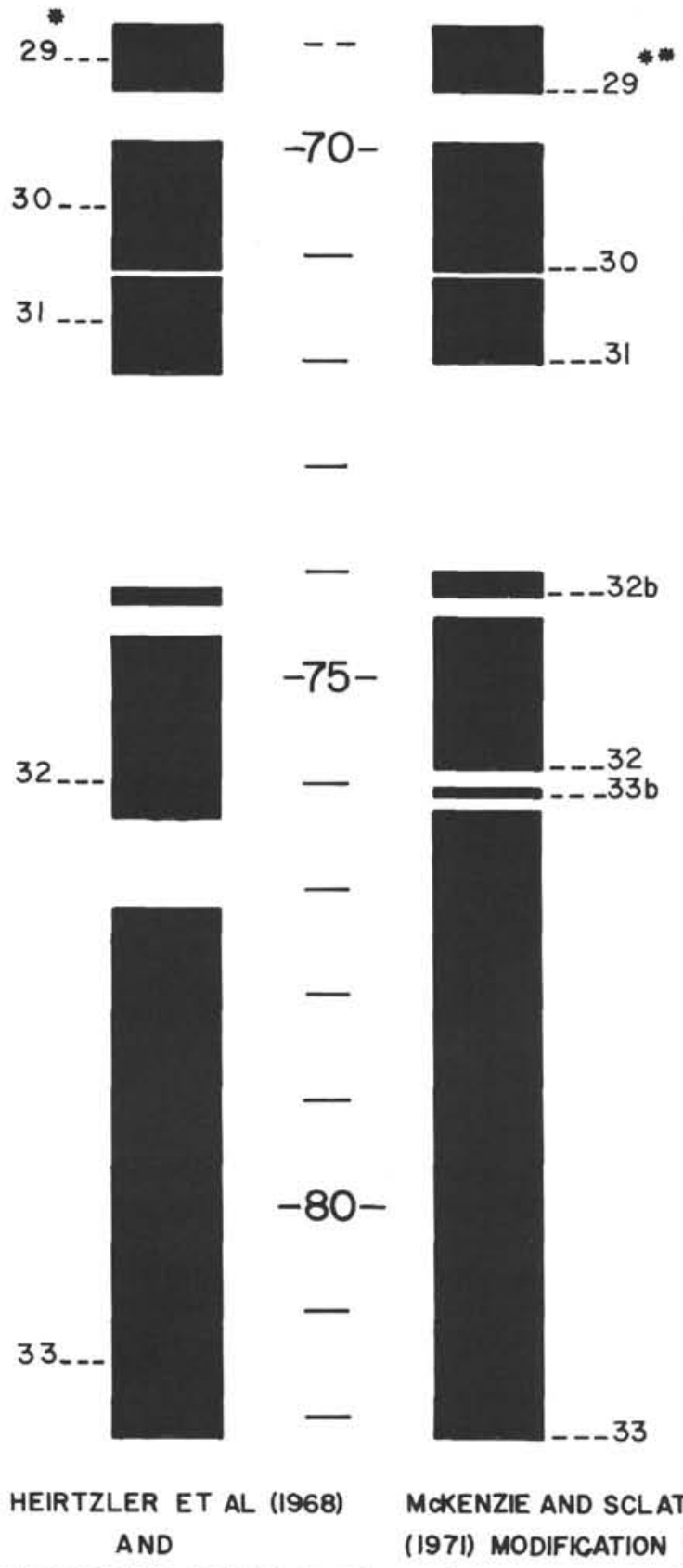

LARSON AND PITMAN (1972)

\section{MCKENZIE AND SCLATER (I97I) MODIFICATION OF HEIRTZLER ET AL (1968) AND LARSON AND PITMAN (1972)}

Figure 1. Comparison of the Heirtzler et al. (1968) and McKenzie and Sclater (1971) time scales for the Late Cretaceous. The single (*) asterisk indicates the numbering scheme of Larson and Pitman (1972). The (**) double asterisk indicates the numbering scheme in Sclater and Fisher (in preparation) and this volume. For this volume, all numbers refer to the end of the normal period except those with the (b) which indicate the end of the first normal reversal at the beginning of a period of dominantly normal polarity.
For the comparison of the two time scales, the numbered magnetic anomalies on the V-20 profile have been plotted against distance from the mid-Atlantic Ridge (Heirtzler et al., 1968, Figure 1). The age of the basal sediments from the JOIDES sites as plotted against magnetic anomaly numbers and hence against distance in the south Atlantic (Figure 2). Four sites-19, 39, 213, and 20-have biostratigraphic ages significantly younger than those predicted by the magnetics. They all fall well below the straight line computed assuming a spreading rate of $1.9 \mathrm{~cm} / \mathrm{yr}$.

An alternative magnetic time scale could be constructed by assuming a constant spreading rate in the north Pacific prior to 20 m.y. B.P. (Jarrard, unpublished manuscript, lightly dashed line, fig. 2). This gave a better match to the older data, but it seems implausible to assume a constant rate of opening for the Pacific in as much as Atwater and Menard (1970) present evidence of a large change in spreading direction between anomalies 19 and 22 .

Another method of obtaining a magnetic time scale in better agreement with the sediment ages is to assume a constant but slightly faster rate of opening in the south Atlantic. The spreading rate was determined by assuming a constant rate and taking Site 20 at the end of anomaly 30 with a biostratigraphic age of $66 \mathrm{~m} . y$. B.P. as the end point. This gave a rate of slightly greater than $2.0 \mathrm{~cm} / \mathrm{yr}$. Before the Heirtzler et al. (1968) scale could be adjusted it was necessary to account for the fact that the magnetic anomaly time scale is known to be accurate back to 3.36 m.y. B.P. from radiometric dating of reversals on land. This was done by assuming that the ages for the reversals given by the Heirtzler et al. (1968) for time prior to anomaly 5 were correct; the age of the reversals before this time were then reduced by roughly $8 \%$. The 10 m.y. B.P. age for the change from the Heirtzler et al. (1968) time scale was chosen deliberately. Anomaly 5 is the furthest distinctive anomaly from the axis of spreading, whereby assuming a spreading rate of $2.04 \mathrm{~cm} / \mathrm{yr}$ and using the Heirtzler et al. (1968) time scale, no detectable difference in distance between the observed and theoretical anomalies could be seen (c.f. the position of anomaly 5 on the V-20 profile on Figure 2).

A preferred magnetic time scale compatible with the Heirtzler et al. (1968) scale to 10 m.y. B.P., and Site 20 in the south Atlantic was computed using the equation:

$$
t_{n}^{\prime}=\left(t_{n}-10.0\right) \times 0.92+10.0 \text {, }
$$

where $t_{n}^{\prime}$ is the preferred time for a reversal in millions of years and $t_{n}$ is the time of the $n^{\text {th }}$ reversal from the Heirtzler et al. (1968) time scale. A new chart of anomaly number versus biostratigraphic age was constructed (Figure 2). The major change from the Heirtzler et al. (1968) time scale and a more recent update by Larson and Pitman (1972) is the position of the Cretaceous/Tertiary boundary. This boundary was initially thought to come between anomalies 26 and 27 . The boundary is placed between 29 and 30 . The major advantage of the new scale is that the biostratigraphic and magnetic time scales give close to the same age for the basement at Sites 19, 39, 213, and 20. 
TABLE 2

DSDP Sites on Identifiable Magnetic Anomalies with Good Sediment Basement Contacts

\begin{tabular}{|c|c|c|c|c|c|c|c|c|c|c|c|}
\hline Site & Latitude & Longitude & $\begin{array}{l}\text { Basal } \\
\text { Contact } \\
\text { Core }\end{array}$ & Description of Contact & $\begin{array}{l}\text { Diagnostic } \\
\text { Calcareous } \\
\text { Zone }\end{array}$ & $\begin{array}{l}\text { Nannofossils } \\
\text { Age (m.y.) }\end{array}$ & $\begin{array}{l}\text { Diagnostic } \\
\text { Planktonic } \\
\text { Zone }\end{array}$ & $\begin{array}{l}\text { Foraminifera } \\
\text { Age (m.y.) }\end{array}$ & $\begin{array}{l}\text { Hard Rock } \\
\text { Type }\end{array}$ & $\begin{array}{c}\text { Magnetic } \\
\text { Anomaly } \\
\text { No. }\end{array}$ & $\begin{array}{l}\text { Magnetic } \\
\text { Anomaly } \\
\text { Age (m.y.) }\end{array}$ \\
\hline 14 & $28^{\circ} 19.9^{\prime} \mathrm{S}$ & $20^{\circ} 56.5^{\prime} \mathrm{W}$ & 10 & $\begin{array}{l}\text { Basalt, possibly intrusive, } \\
\text { fossils (Core } 9 \text { ) immedi- } \\
\text { ately above are used for } \\
\text { age. }\end{array}$ & $\begin{array}{l}\text { Helicosphaera } \\
\text { reticulata }\end{array}$ & $37 \pm 1.0$ & $\begin{array}{l}\text { Globorotalia } \\
\text { cerroazulensis }\end{array}$ & $38-41$ & $\begin{array}{l}\text { Aphanitic } \\
\text { basalt }\end{array}$ & $\begin{array}{l}\text { Negative } \\
\text { anomaly west } \\
\text { of } 13 \text {, possi- } \\
\text { bly } 15\end{array}$ & $39-41$ \\
\hline 15 & $30^{\circ} 53.4^{\prime} \mathrm{S}$ & $17^{\circ} 59.0^{\prime} \mathrm{W}$ & 10 & $\begin{array}{l}\text { Basalt, possibly extru- } \\
\text { sive; nannos in Core } 10 \\
\text { in contact with basalt; } \\
\text { same as in Core } 9 \text { above; } \\
\text { nanno ages from Core } 9 \text {. }\end{array}$ & $\begin{array}{l}\text { Triquetrorhabdulus } \\
\text { carinatus }\end{array}$ & $20-22.5$ & $\begin{array}{l}\text { Globigerinita dis- } \\
\text { similis-Globigeri- } \\
\text { nita stainforthi }\end{array}$ & $\begin{array}{l}? \\
17.5-21\end{array}$ & $\begin{array}{l}\text { Aphanitic } \\
\text { basalt }\end{array}$ & 6 & $20-21$ \\
\hline 16 & $30^{\circ} 20.2^{\prime} \mathrm{S}$ & $15^{\circ} 42.8^{\prime} \mathrm{W}$ & 12 & $\begin{array}{l}\text { Basalt chip only, possi- } \\
\text { bly extrusive; nannos and } \\
\text { forams in Core } 11 \text { imme- } \\
\text { diately above used for } \\
\text { age. }\end{array}$ & $\begin{array}{l}\text { Triquetrorhabdulus } \\
\text { rugosus, pre- } \\
\text { Ceratolithus }\end{array}$ & $8.5 \pm 0.5$ & $\begin{array}{l}\text { Globigerinoides } \\
\text { ruber, }+ \text { Sphaeroid- } \\
\text { inellopsis seminu- } \\
\text { lina, no Sphaeroid- } \\
\text { inella dehiscens }\end{array}$ & $6-8$ & $\begin{array}{l}\text { Aphanitic } \\
\text { basalt }\end{array}$ & 5 & $9-10$ \\
\hline 19 & $28^{\circ} 32.1^{\prime} \mathrm{S}$ & $23^{\circ} 40.6^{\prime} \mathrm{W}$ & 12 & $\begin{array}{l}\text { Basalt, possibly extru- } \\
\text { sive; nannos with } \\
\text { basalt (Core 12), } \\
\text { forams (Core 11). }\end{array}$ & $\begin{array}{l}\text { Chiphragmolithus } \\
\text { quadratus }\end{array}$ & $46-48$ & $\begin{array}{l}\text { Hantkenina } \\
\text { aragonensis }\end{array}$ & 48 & $\begin{array}{l}\text { Aphanitic } \\
\text { basalt 1 } \\
\text { (vesicular) }\end{array}$ & $\begin{array}{l}\text { Just before } \\
\text { start of } 21\end{array}$ & $53-56$ \\
\hline $20 \mathrm{~A}$ & $28^{\circ} 31.5^{\prime} \mathrm{S}$ & $26^{\circ} 50.7^{\prime} \mathrm{W}$ & 4 & $\begin{array}{l}\text { Basalt (Core 4); possi- } \\
\text { bly extrusive, nannos } \\
\text { in chalk intercalated } \\
\text { with basement. }\end{array}$ & Tetralithus murus & $65-67$ & & & & & \\
\hline $20 \mathrm{C}$ & & & 6 & $\begin{array}{l}\text { Basalt (Core 5); } \\
\text { nannos and forams. }\end{array}$ & & & $\begin{array}{l}\text { Abathomphalus } \\
\text { mayaroensis }\end{array}$ & $65-67$ & $\begin{array}{l}\text { Basaltic } \\
\text { pillow brec- } \\
\text { cia with glass } \\
\text { and marble } \\
\text { fragments }\end{array}$ & End of 30 & $70-72$ \\
\hline 32 & $37^{\circ} 07.6^{\prime} \mathrm{N}$ & $127^{\circ} 33.4^{\prime} \mathrm{W}$ & 14 & $\begin{array}{l}\text { Vesicular basalt, } \\
\text { overlain by clay } \\
\text { and basalt in } \\
\text { Core } 13 \text {. }\end{array}$ & $\begin{array}{l}\text { Coccolithus } \\
\text { bisectus } \\
\text { C. bisectus- } \\
\text { Reticulofenestra } \\
\text { umbilica }\end{array}$ & $34-37.5$ & & & $\begin{array}{l}\text { Basalt, glassy } \\
\text { and vesicular }\end{array}$ & 13 & $37-39$ \\
\hline 36 & $40^{\circ} 59.1^{\prime} \mathrm{N}$ & $130^{\circ} 06.6^{\prime} \mathrm{W}$ & 14 & $\begin{array}{l}\text { Basalt nannoplankton } \\
\text { with small fragments } \\
\text { of basalt in Core } 13\end{array}$ & Discoaster exilis & $10.5-12.5$ & $\begin{array}{l}\leqslant \mathrm{N}-13 \text { Core } 12 \\
\mathrm{~N}-10, \text { Core } 12-6\end{array}$ & $\begin{array}{l}<14 \text { m.y. } \\
\leqslant 14-15\end{array}$ & Basalt & $\begin{array}{l}\text { On disturbed } \\
\text { anomalies end } \\
\text { of } 4 \text { above } \\
\text { and below }\end{array}$ & $7-9$ \\
\hline 39 & $32^{\circ} 43.4^{\prime} \mathrm{N}$ & $139^{\circ} 34.3^{\prime} \mathrm{W}$ & & $\begin{array}{l}\text { Center bit had black } \\
\text { aphanitic basalt - } \\
\text { contact not cored; } \\
\text { amorphous iron oxide } \\
\text { overlies basalt. }\end{array}$ & $\begin{array}{l}\text { Marthasterites } \\
\text { tribrachiatus }\end{array}$ & $51-52$ & P-6 & $52-54$ & $\begin{array}{l}\text { Black apha- } \\
\text { nitic basalt }\end{array}$ & $\begin{array}{l}\text { Extrapolated } \\
\text { end of } 24\end{array}$ & $60-62$ \\
\hline 213 & $10^{\circ} 12.7^{\prime} \mathrm{S}$ & $93^{\circ} 53.8^{\prime} \mathrm{E}$ & 17 & $\begin{array}{l}\text { Basalt with interbedded } \\
\text { calcareous sediments. }\end{array}$ & $\begin{array}{l}\text { Discoaster } \\
\text { mohleri }\end{array}$ & $57-58$ & $\mathrm{P}-4$ & $56-58$ & $\begin{array}{l}\text { Weathered } \\
\text { pillow } \\
\text { basalt }\end{array}$ & $\begin{array}{l}\text { Beginning of } \\
26\end{array}$ & $63-65$ \\
\hline
\end{tabular}

${ }^{a}$ From Heirtzler et al., 1968 


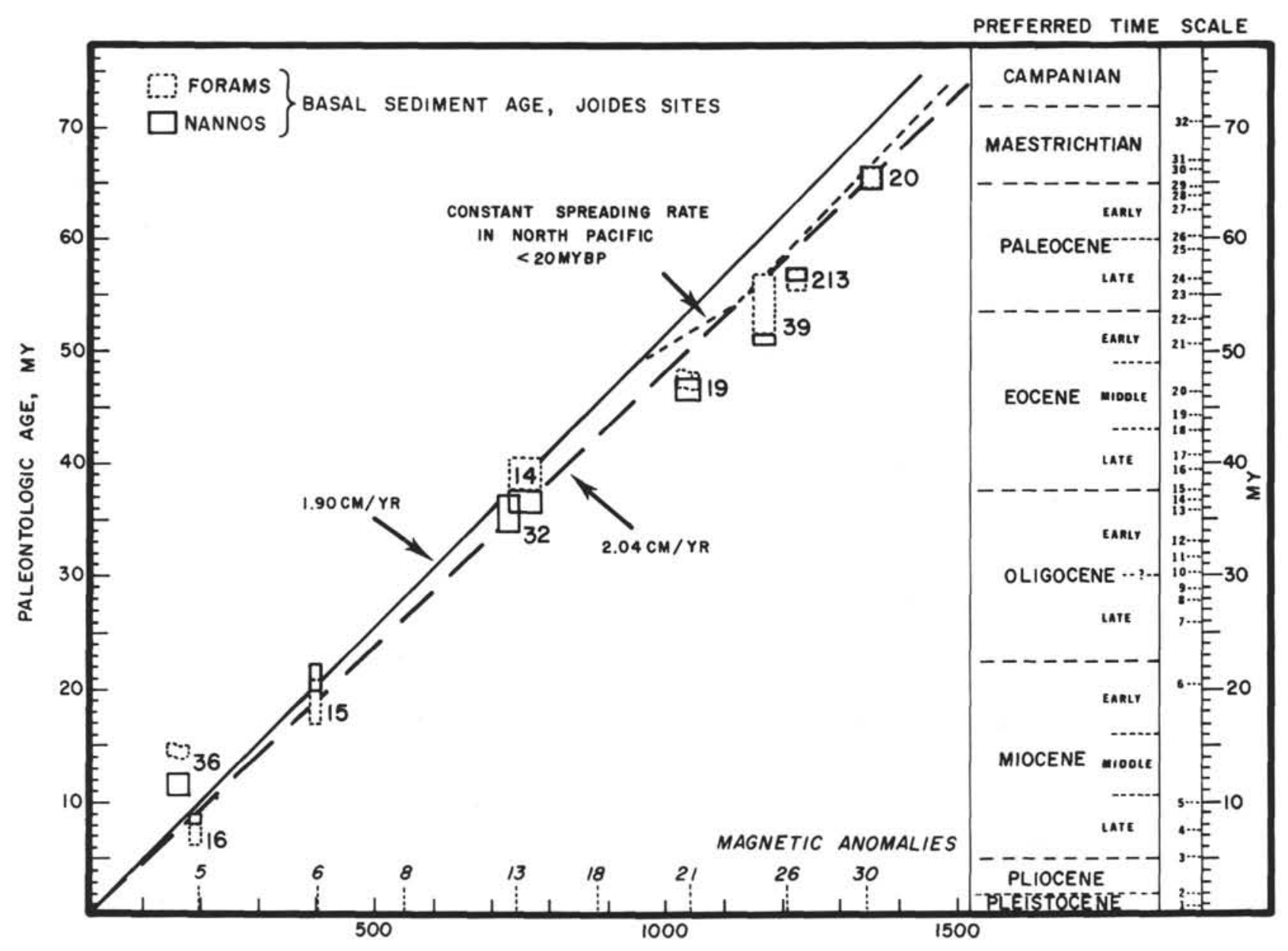

DISTANCE FROM MID-ATLANTIC RIDGE IN KM ALONG V-20 PROFILE (HEIRTZLER ET AL., 1968)

Figure 2. Comparison of the paleontological (from Berggren, 1972) and magnetic anomaly (from Heirtzler et al., 1968) age estimates of the basement at eight JOIDES sites. The dashed and solid rectangles represent uncertainty in the age of foraminifera and nannofossils identification, respectively. The heavy continuous line represents the time scale of Heirtzler et al. (1968). The light dashed line shows the adjustments resulting from the assumption of a constant spreading in the north Pacific rather than the south Atlantic, prior to 20 m.y. B.P. The heavy dashed line assumes a constant rate of $2.04 \mathrm{~cm} / \mathrm{yr}$ in the south Atlantic. The adjusted reversal time scale $\mathrm{t}_{\mathrm{n}}$ was determined from the equation $t_{n}^{\prime}=\left(t_{n}-10.0\right) \times 0.92+10$, where $t_{n}$ is the time of the $n$th reversal on the Heirtzler et al., 1968 time scale. At Sites 15 and 16 the uncertainty in the magnetic anomaly age is assumed to be \pm 0.5 m.y.; at Site 14 it is \pm 1.5 m.y.; at all others it is \pm 1.0 m.y.

\section{DISCUSSION $^{1}$}

A straight line with a slope of $2.04 \mathrm{~cm} / \mathrm{yr}$ gives a fairly good fit to the plot of biostratigraphic age versus distance from the mid-Atlantic Ridge. As there are only eight points on the plot and the errors in biostratigraphic ages are of the same order as the age discrepancies, there is no advantage to treating the data statistically. A low-order polynomial fit to the mid-points of the rectangles would probably indicate significant increase in spreading rate in the south Atlantic at a distance of between 700 and $1000 \mathrm{~km}$ from the ridge

\footnotetext{
${ }^{1}$ We are grateful to Roger Larson for raising the following points.
}

axis. There is no reason to expect that the mid-Atlantic Ridge has spread at a constant rate for the past 70 m.y. A constant spreading rate is a simple artifice to generate the entire time scale. With presently available data, there is no justification for considering a more complicated model.

A further note of caution is necessary about the sites that have been rejected. Sites 10 and 36 are the most critical. Site 36 has a basal sediment age that is considerably greater than that given by the magnetic anomalies to the north and south. It is unsatisfactory to have to reject this site on the basis of two nearby seamounts and the reworking of material from the Mendocino Ridge. The justification for neglecting Site 10 is that the anomaly identification is not good. However, should it turn out to 
be correct then the preferred time scale could be significantly in error by the time of anomaly 32 . The above comments have been added to emphasize the difficulties inherent in constructing a time scale which agrees with both the magnetic and biostratigraphic information.

\section{ACKNOWLEDGMENTS}

We would like to thank David Johnson and Tony Pimm for help with the preliminary manuscript and our colleagues on Leg 22 for help and encouragement. Roger Larson reviewed the manuscript. The research covered in this paper was supported by the Office of Naval Research.

\section{REFERENCES}

Atwater, T. and Menard, H. W., 1970. Magnetic lineations in the North-east Pacific: Earth Planet. Sci. Lett. v. 7, p. 445 .

Berggren, W. A., 1972. A Cenozoic timescale-some implications for regional geology and paleobiogeography: Lethaia, v. 5, p. 195-215.

Chase, T. E., Menard, H. W., and Mammerickx, J., 1970. Bathymetry of the Northern Pacific charts (1-10): Institute of Marine Resources, La Jolla, California.

Dickson, G. O., Pitman, W. C., III, and Heirtzler, J. R. 1968. Magnetic anomalies in the South Atlantic and ocean floor spreading: J. Geophys. Res., v. 73, p. 2087-2100.

Dalrymple, G. G., 1972. Potassium Argon dating of geomagnetic reversals and North American glaciations. In Calibration of Homward Evolution, Bishop, W. W. and Miller, J. A., (Eds.), Edinburgh (Scottish Academic Press), p. 109-134.

Doell, R. R., Dalrymple, G. B., and Cox, A., 1966. Geomagnetic polarity epochs: Sierra Nevada data: J. Geophys. Res., v. 3, p. 531

Heirtzler, J. R., Dickson, G. O., Herron, E. M., Pitman, W. C., and LePichon, X., 1968. Marine magnetic anomalies, geomagnetic field reversals, and motions of the ocean floor and continents: J. Geophys. Res., v. 73, p. 2119-2136.
Herron, E. M., 1972. Sea-floor spreading and the Cenozoic history of the East-Central Pacific: Geol. Soc. Am. Bull., v. 83, p. $1671-1692$.

Larson, R. L. and Pitman, W. C., III, 1972. World wide correlation of Mesozoic magnetic anomalies and its implications: Geol. Soc. Am. Bull., v. 83, p. 3645-3662.

Mammerickx, J., Detrick, R., and Sclater, J. G. Fracture zones and magnetic lineations in the South Central Pacific: unpublished manuscript.

Maxwell, A. E., Von Herzen, R. P., Andrew, J. E., Boyce, R. E., Milow, E. D., Hsu, K. J., Percival, S. F., Saito, T., 1970. Initial Reports of the Deep Sea Drilling Project, Volume III: Washington (U. S. Government Printing Office).

McKenzie, D. and Sclater, J. G., 1971. The evolution of the Indian Ocean since the Late Cretaceous: Geophys. J. Roy, Astr. Soc., v. 25, p. 437-528.

McManus, D. A., Burns, R. E., Weser, O., Vallier, T., von der Borch, C., Olsson, R. K., Goll, R. M., Milow, E. D., 1970. Initial Reports of the Deep Sea Drilling Projects; Volume V: Washington (U. S. Government Printing Office).

Peterson, M. N. A., Edgar, N. T., Cita, M., Gartner, S., Jr., Goll, R., Nigrini, C., von der Borch, C., 1970. Initial Reports of the Deep Sea Drilling Project; Volume II: Washington (U. S. Government Printing Office).

Pitman, W. C., III, and Heirtzler, J. R., 1966. Magnetic anomalies over the Pacific Antarctic Ridge: Science, v. 154, p. 1164 .

Pitman, W. C., III and Talwani, M., 1972. Sea floor spreading in the North Atlantic: Geol. Soc. Am. Bull., v. 83 , p. 619-646.

Saito, T., Ewing, M., and Burke, L. H., 1966. Tertiary sediment from the mid-Atlantic Ridge: Science, v. 151, p. 1075-1079.

Sclater, J. G. and Fisher, R. L., in preparation. The evolution of the east central Indian Ocean with emphasis on the tectonic setting of the Ninetyeast Ridge: submitted to Geol. Soc. Am. Bull.

Tracey, J. I., Jr., Sutton, G. H., Nesteroff, W. D., Galehouse, J., von der Borch, C., Moore, T., Lipps, J., Bilail nl Hag, U. S., Bechmann, J. P., 1971. Initial Reports of the Deep Sea Drilling Project, Volume VIII: Washington (U. S. Government Printing Office). 